\title{
定常円旋回時の自動車に作用する空気力について
}

中島 卓司 ${ }^{* 1}$, 坪倉 誠 ${ }^{*},{ }^{* 7}$, 岡田 義浩*3 農沢 隆秀*4，溝兼 通矢*5，土井 康明*6

\section{Aerodynamic force acting on a road vehicle in steady-state cornering}

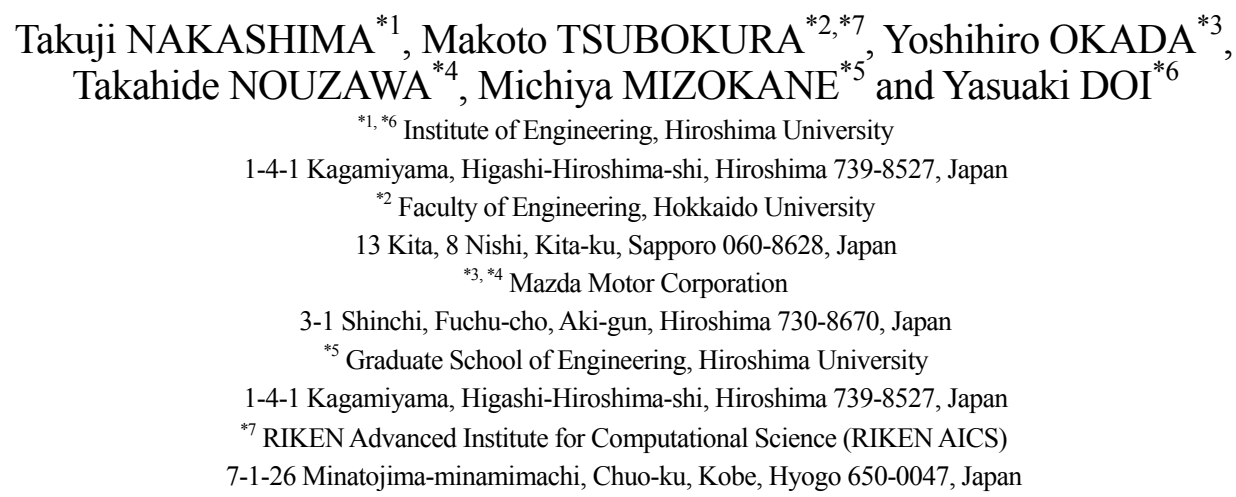

Received 4 June 2014

\begin{abstract}
The objective of this study is to investigate aerodynamics and its generating mechanism of a road vehicle in steady-state cornering, which is the most basic cornering condition. The vehicle motion in the steady-state cornering was defined on a frame of reference fixed on the vehicle and it was divided into a rotation around a vertical axis and a sideslip. Then, aerodynamic force generated by each motion and its generating mechanism was discussed. In order to reproduce an effect of the rotational motion, a towing tank experiment was conducted to measure the fluid-dynamic force acting on a one-fifth-scale model of a sedan-type road vehicle. Assuming that the fluid-dynamic forces are expressible as a linear superposition of effects of the rotation and sideslip, first derivatives of the side force and yaw moment with respect to the yaw rate and the lateral velocity were analyzed by a multiple linear regression analysis. From the results of measurement and analysis, it was clarified that the assumption can provide good approximations of the force and the moment within a range of measurement conditions in this study. Regarding the fluid-dynamic side force, the rotation generates a centripetal force of the circular motion and the sideslip generates a force suppressing the slip motion. Regarding the fluid-dynamic yaw moment, the rotation generates a moment suppressing the rotation, and the sideslip generates a moment enhancing the vehicle's slip angle. Aerodynamics of a sedan-type road vehicle was estimated quasi-steadily by multiple regression equations with measured vehicle motion in an on-road test. From this estimation, the effects of both the rotation and the sideslip had the same order of magnitude. This result indicates that the effects of the vehicle's rotational motion have the same level of importance as the effects of the sideslip in vehicle aerodynamics in steady-state cornering.
\end{abstract}

Key words : Aerodynamics, Road vehicle, Steady-state cornering, Yaw motion, Towing tank experiment

\section{1. 緒言}

近年，車両の軽量化や環境負荷低減の観点から，自動車開発における空力設計の重要性が高まっている．注目

No. 14-00300 [DOI: 10.1299/transjsme.2014fe0301]

*1 正員, 広島大学 大学院工学研究院（干739-8527 広島県東広島市鏡山 1 丁目 4-1）

*2 正員, 北海道大学 大学院工学研究院 ( $\bar{T} 060-8628$ 北海道札幌市北区北 13 条西 8 丁目)

*3 正員, マツダ(株) 車両実研部（テ730-8670 広島県安芸郡府中町新地 3-1）

*4 正員, マツダ(株) 技術研究所

*5 広島大学 大学院工学研究科

*6 広島大学 大学院工学研究院

*7 理化学研究所計算科学研究機構（广650-0047 兵庫県神戸市中央区港島南町 7-1-26）

E-mail of corresponding author: nakashima@hiroshima-u.ac.jp 
Nakashima, Tsubokura, Okada, Nouzawa, Mizokane and Doi,

Transactions of the JSME (in Japanese), Vol.80, No.818 (2014)

される空力性能としては，燃費性能に直接寄与寸る空気抵抗が最重要項目であり，現在の設計開発では，一様流 下で車両姿勢を固定した条件での定常 6 分力評価が主となっている.これに対して最近では，高速走行時の直進 安定性や横風に対する安全性，さらには操舵時の安定性等に対する空力性能向上のニーズが高まっている．例え ば，走行中の車両に作用する変動風外乱や路面凹凸などの外乱に伴う車両姿勢変化に対する空力安定性の影響に ついて, 車両を強制加振して模擬することにより，その過渡的空気力を計測した風洞実験(河上他, 2010, Theissen, et al., 2011)や非定常乱流シミュレーション(佐藤他，2010, Cheng, et al., 2013)が報告されている. 一方，このよう な走行中の外乱に対寸る受動的な運動安定性に対して, 運転手による操舵を考慮したより能動的な車両運動に対 する空力安定性（空力操安性）についても, 近年, 実車走行試験に基づく計測(岡田他, 2014)や, 数值シミュレ ーション(Tsubokura, et al., 2012)が実施され, 特に蛇行運動時の安定性に寄与する非定常流れ現象の存在が指摘さ れている. しかしこのような操舵時の車両に作用する空気力については, 既存の風洞実験設備では現象の再現が 難しい上, その空力発生要因が複合的であることから, 十分な理解がされているとは言えないのが現状である.

操舵時の自動車の主要な運動は, 車両の軌道変更に伴う旋回運動であり, これは直進走行時の車両運動に対し て，車両重心を通る鉛直軸周りの回転運動（ヨー運動）と横すべり運動（タイヤのすべりに伴う車両横方向への 運動) が複合した合成運動とみることができる. (一般的な操舵運動では, そのような水平面内の運動に車両前後 軸周りの回転運動（ロール運動）を主とする鉛直方向の運動が加わることで，さらに複雑なものとなっているこ とに注意されたい.）したがって旋回運動を車両が地表に対して相対的に回転する運動であると捉え，この運動を 風洞等の一様流下で再現すべく車両に強制的なヨー回転を加えることも考えられるが，この場合，車両の回転に 伴って接近流の風向が変化することから，実際の旋回運動（例えば，定常旋回運動であれば接近流の車両に対す る風向は変化しない）とは条件が異なってしまう。このような実験の困難さから，自動車の空力において旋回走 行時の回転運動の影響を独立に議論した例は非常に少ない.このため, 操舵時の主要運動である旋回運動に起因 して生じる空気力を評価し, 特にその回転運動による影響を調べることは, より適切な空力操安性評価を行う上 で重要な課題となっている.

そこで本研究では，旋回運動のうち最も基本的な定常円旋回運動に着目し，車両に作用する空力とその発生メ カニズムについて調べることを目的とする，そのため，定常円旋回時の車両運動を，車両に固定した座標系に基 ついて鉛直軸周りの回転運動と横す心゙り運動に分解し，各運動に対して発生する空気力について明らかにすると ともに，その発生メカニズムについて考察する. 特に回転運動の効果を再現するために, 風洞実験に替わってこ こでは曳航水槽を用いた水槽実験を行い，車両模型に作用する流体力を計測する.

\section{2. 記 号}

$\begin{array}{ll}B & : \text { 車両模型全幅 } \\ C_{D} & : \text { 抗力係数 } \\ C_{L f} & : \text { 前輪軸位置における揚力係数 } \\ C_{L r} & : \text { 後輪軸位置における揚力係数 } \\ C_{S} & : \text { 横力係数 } \\ C_{S, 0} & : C_{S} \text { の近似式における定数項 } \\ C_{Y M} & : \text { 水一メント係数 } \\ C_{Y M, O} & : C_{Y M} \text { の近似式における定数項 } \\ D & : \text { 曳航時の車両模型の没水深さ } \\ d_{F} & : \text { 仮底平板の没水深さ } \\ F r_{d} & : \text { 模型没水深さに基づく Froude 数 } \\ g & : \text { 重力加速度 } \\ h & : \text { 曳航時の車両模型全高 } h=H+h_{c} \\ h_{c} & : \text { タイヤ下面と仮底平板の隙間高さ } \\ H & : \text { 車両模型全高 }\end{array}$

$B \quad$ : 車両模型全幅

$C_{D}$ : 抗力係数

$C_{L f} \quad$ : 前輪軸位置における揚力係数

$C_{S} \quad$ : 横力係数

$C_{S, 0}: C_{S}$ の近似式における定数項

$C_{Y M}:$ : コーモーメント係数

$C_{Y M, 0}: C_{Y M}$ の近似式における定数項

$D$ : 曳航時の車両模型の没水深さ

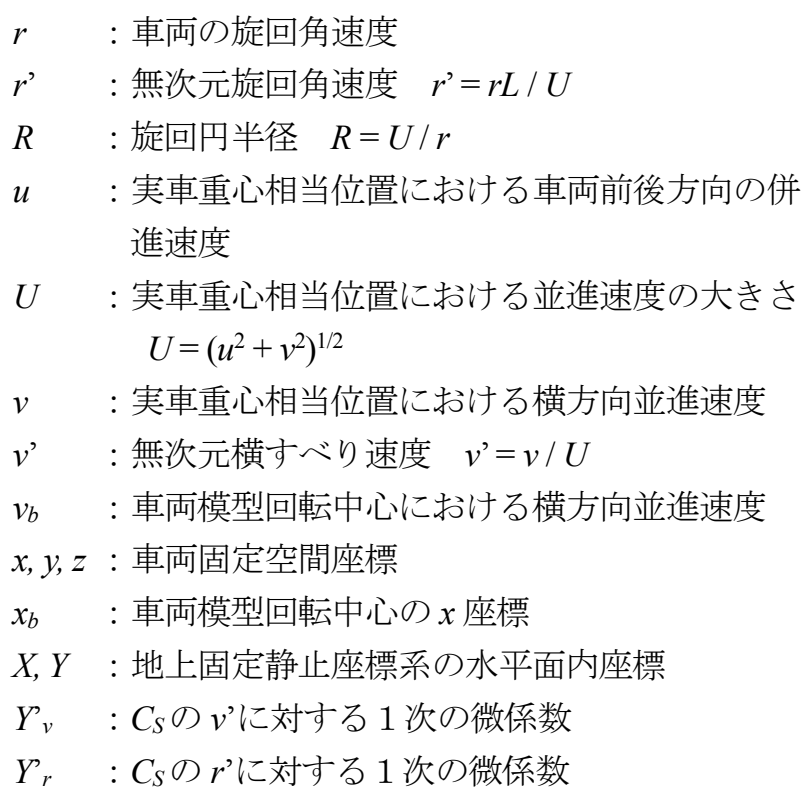


Nakashima, Tsubokura, Okada, Nouzawa, Mizokane and Doi,

Transactions of the JSME (in Japanese), Vol.80, No.818 (2014)

$L$ : 車両模型全長

$L_{w} \quad$ : 車両模型ホイールベース長さ

(前後輪軸間距離)

$N^{\prime}{ }_{v}: C_{Y M}$ の $v^{\prime}$ に対する 1 次の微係数

$N^{\prime}{ }_{r}: C_{Y M}$ の $r$ に対する 1 次の微係数 $\beta$ : 実車重心相当位置におけるすべり角

$$
\beta=\sin ^{-1}(v / U)
$$

$\beta_{b} \quad$ : 車両模型回転中心におけるすべり角

$$
\beta_{b}=\sin ^{-1}\left(v_{b} / U\right)
$$

$\psi$ : 車両前後軸の $X$ 軸に対する傾き角（ヨー角）

\section{3. 手法}

\section{$3 \cdot 1$ 対象車両形状}

本研究で対象とする車両形状について述べる. 本研究で注目する旋回運動中の自動車の空力特性については, 関与寸る流動メカニズムが明らかになっていないため, 自動車の周囲に形成される多くの特徵的流れ構造（農沢 他，2009）を再現した形状を対象に検討寸ることが必要と考えられる．そこで，そのような流れ構造の形成が確 認されており，また，高速操安性のニーズも高いセダン型車両を対象車両として選択した．ただし，実際の計測 対象形状としては，対象としたセダン型車両周りの流れ構造を模擬しながら，エンジンルーム等を除き，車両の 形状を一部簡略化したモデル形状(Tsubokura, et al., 2012)を用いることとした．車両寸法は，曳航水槽試験設備の 大きさや水面の影響等を考慮して実車 $1 / 5$ スケールの縮小模型とし， $L=0.934 \mathrm{~m}, L_{w}=0.535 \mathrm{~m}, B=0.391 \mathrm{~m}, H=0.278 \mathrm{~m}$ である．同車両モデルの正面斜視図および五面図を図 1 に示寸．正面斜視図中には，走行する車両に固定された 座標系（本稿では，以降「車両固定座標系」と称する）の座標軸とその軸周りの回転の定義を併せて示した．本 稿で用いる車両固定座標系は，車両前後方向の前向きを $x$ 軸正，車両左右方向の左向きを $y$ 軸正，車両高さ方向 の上向きを $z$ 軸正とした座標系である. また $, x, y, z$ 各軸周りの回転については各軸の右回り方向を正とし, それ ぞれロール，ピッチ，ヨーと呼称することとする．なお，座標系の原点は本自動車モデルの原型であるセダン型 乗用車の重心位置を参考に決定し，その車両前後方向位置は，前後輪軸間の中心（ホイールベースセンタ）から $0.064 L_{w}$ 前方, 車両左右方向位置は車両中心とした. 本稿ではこの座標系を用いて車両運動を定義するとともに, 各軸方向の力および各軸周りのモーメントとして発生流体力を整理する.



(a) Front perspective view

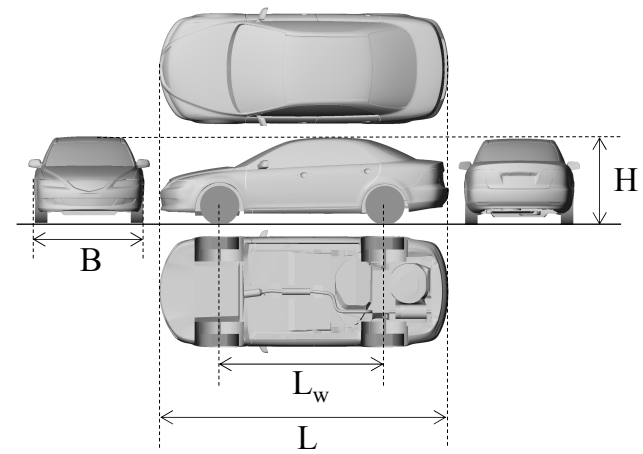

(b) Five orthogonal views

Fig.1 Simplified model of a sedan-type road vehicle. A one-fifth-scale model of this simplified vehicle's geometry is an objective of this study. Figure (a) includes definitions of coordinate axes fixed on the vehicle and rotations around the axes.

\section{$3 \cdot 2$ 車両運動の定義}

水平面内を定常円旋回運動している自動車は，車両固定座標系で見た場合， $x$ 軸および $\mathrm{y}$ 軸方向の車両重心の 並進運動と, 重心を通る $z$ 軸周りの回転運動が合わさった，合成運動とみることができる．ここで，前者の並進 速度と後者の回転角速度の積が，車両重心が円周軌道を描く公転運動を表現し，後者の回転運動が車両の重心回 りの自転運動を表現する，ところで，車両が旋回運動をするためには，各タイヤが横すべりしてタイヤ力を生じ て横力とヨーモーメントを発生する必要がある. タイヤの横す心゙りは, 操舵によるタイヤの傾きに加え, 車両に 生じる重心回りのヨー回転運動と車両重心の横移動によって与えられる. このため, 旋回運動中の自動車は, 通 


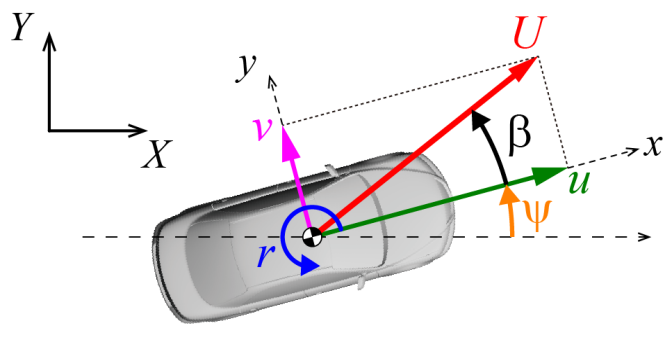

(a) Definition of vehicle-motion parameters

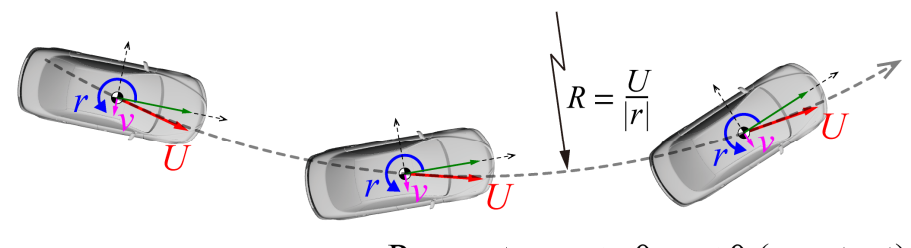

Parameters: $r>0, v<0$ (constant)

Fig.2 Target vehicle motion and its parameters. Figure (a) shows the definition of parameters describing the vehicle motion in cornering. The motion is divided into two components - yaw rotation and sideslip motion — and they are parameterized by an angular velocity in the yaw direction $r$ (yaw rate) and a lateral velocity $v$, respectively. Figure (b) shows a schematic view of steady-state cornering in the case of left turning described by the parameters defined in Figure (a).

常，車両の重心位置において横方向の速度 $v$ （以降，横すべり速度と称する）を生じている. 即ち，旋回運動す る車両は車両前後軸から角度 $\beta=\sin ^{-1}(v / U)$ だけ傾いた斜め前方へ並進運動していることが一般的である．定常円 旋回運動する自動車においては，空気力を無視すると車両の慣性力とタイヤ力が釣合状態にあり，U，r，および 車両重量とタイヤ特性から $\beta$ が決まる. なお，このす心゙り角 $\beta$ は図 $2(a)$ に示す通り，一般的な翼の迎角とは定義が 逆であることに注意されたい. また, 本稿では $\beta$ を直接の旋回運動パラメータとして用いず, 旋回運動を $z$ 軸周り の回転角速度である旋回角速度 $r$ と車両前後方向速度 $u$ ，および横すべり速度 $v$ によって表現することとする. すると，本研究で対象とする定常円旋回運動は，図 $2(b)$ に示すように，r, $u, v$ が時間的に一定であり，かつ $r$ が 0 ではない值（図の時計回り旋回時では, $u, v$ は正で $r$ は負）となる状態と言い換えることができる.また，本稿で は車両運動を表すパラメータとして，r,vをそれぞれ無次元化した $r^{\prime}=r /(U / L), v^{\prime}=v / U$ を用いることとする. こ

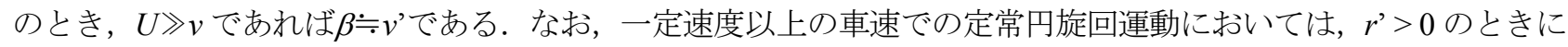
$\beta$ は負, 即ち $v^{\prime}<0$ となることが知られており(安倍, 2012), 一般的な高速走行条件における定常円旋回運動では $r^{\prime}$ と $v^{\prime}$ は異符号となる. また，実際の自動車による定常円旋回運動では， $z$ 軸方向の定常変位と $x$ 軸および $y$ 軸周 りの定常回転角も発生するが，ここではそのような鉛直方向の定常的な車両姿勢変化は無視することとする.

\section{$3 \cdot 3$ 电航水槽試験法}

\section{$3 \cdot 3 \cdot 1$ 曳航水槽試験装置}

本研究で用いた広島大学所有の曳航水槽試験装置の概略を図 3 に示す. 同水槽試験装置は, 水槽両脇に敷設さ れた線路上を走行するモータ駆動の台車（以降, 主台車と称する）が, 長さ $100 \mathrm{~m}$, 幅 $8 \mathrm{~m}$, 深さ $3.6 \mathrm{~m}$ の水槽上 方を長さ方向に移動し，その下方に支持された模型を曳航することで，模型に作用する流体力や模型周囲の流場 を計測する試験装置である。また，主台車上には，模型を固定して水槽幅方向の並進運動と鉛直軸周りの回転運 動を与える機構（以降，副台車と称する）が設置されている. 本研究ではこれらを用いて車両模型に $x, y$ 方向の

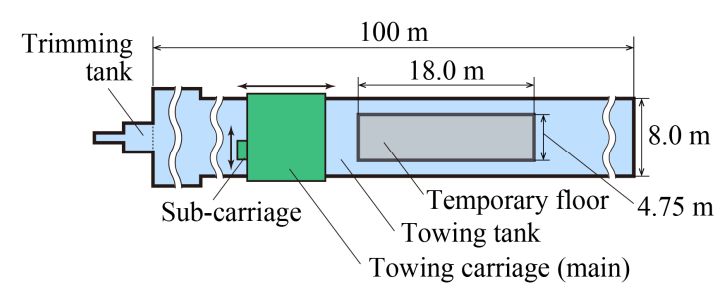

(a) Plan view

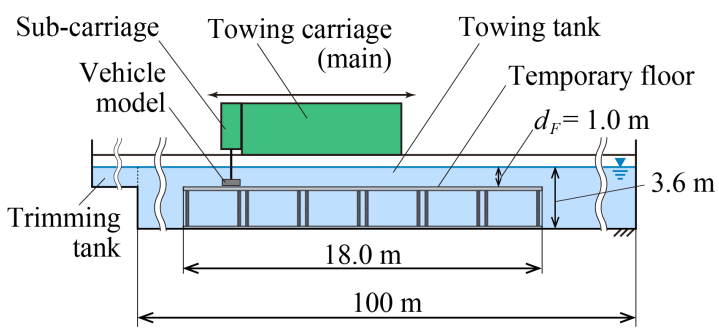

(b) Side view

Fig.3 Schematic views of a towing tank facility. The vehicle model was towed by a main towing carriage in the longitudinal direction of the tank, and it was also actuated in the span wise direction of the tank and in the rotational direction around the vertical axis by a sub-carriage installed on the main carriage. The vehicle running on the ground was simulated by the model towed above a temporary floor, which was installed in the middle of the tank at a depth of $1.0 \mathrm{~m}$. 
並進運動と $z$ 軸周りの回転運動を与え, 主副両台車を連動制御することで定常円旋回運動および直線運動を与え た. また，水槽中央部に長さ $18 \mathrm{~m}$ ，幅 $4.75 \mathrm{~m}$ の浅水域試験用の昇降式仮底が設置されており，この平板を水深 $1.0 \mathrm{~m}$ の位置に固定することで地面に見立て，その直上で自動車モデルを曳航することにより地上を走行する自動 車を模擬した.

供試模型は，切削加工用合成木材（三洋化工株式会社製サンモジュール No.8K）を NC 加工して製作した．そ の外観写真と内部構造図，および曳航時の設置概略図を図 4 に示す。同模型は車両下部および左右上部の 3 部品 から成り，支柱が貫通するための翼型穴と検力装置を内蔵可能な内部空間を有する. 副台車下部に固定された支 柱が, 模型上面の翼型貫通穴を通って模型内部の防水型 6分力検出器 (日章電機株式会社製LMC-6566A -200NWP) を支持し, 模型はその 6 分力検出器の検力面に固定される形で支持されている. このような模型支持構造とする ことで, 検力值から支柱に作用する外力を排除し, 模型のみに作用する外力を計測した. なお， 6 分力検出器の 検力中心位置は，車両幅方向にはその中央，車両前後方向には浮力と重力の合ピッチモーメントがゼロとなる点 とし, 副台車の回転機構の回転軸も, この点を通過するようにした. (この場合, $x$ 座標は $x_{b}=-0.167 L_{w}$ となった.) ただし本稿では, 運動パラメータや計測されたモーメントについて, すべて $3 \cdot 1$ 節で定義した車両固定座標系原 点を基準とする值に変換して記載している．また，支柱は模型近傍の流れ場を極力乱さないようステンレス製円 柱後部に樹脂製の翼型カバーを付加した翼型断面構造とし，水面近傍には支柱による造波を抑制するためのアク リル製円盤を付加した. 計測に用いた 6 分力検出器の出力は, 直流型歪増幅器 (日章電機株式会社製 DSA-100B) により増幅し，A/D 変換ボードによるデジタル化を行って，サンプリング間隔 $10 \mathrm{~ms}$ で PC に記録した.

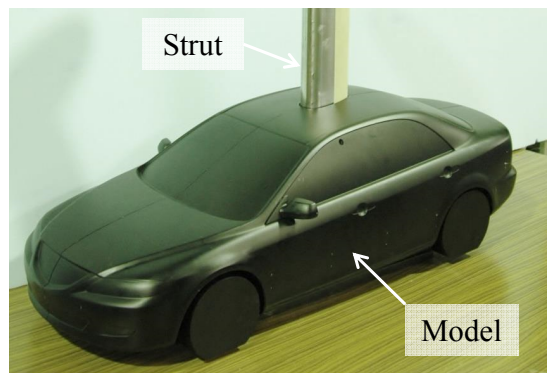

(a) Photograph of appearance

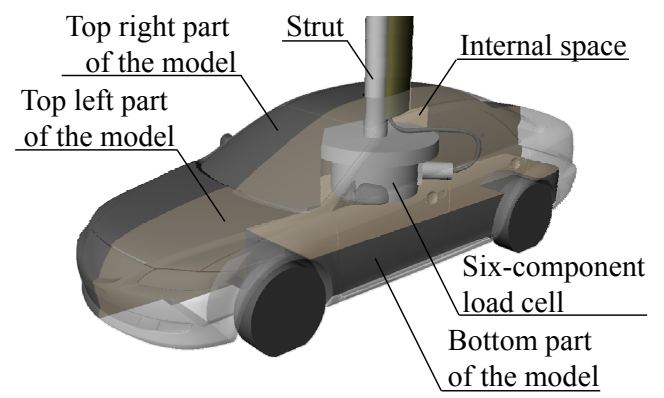

(b) Internal configuration of the experimental model

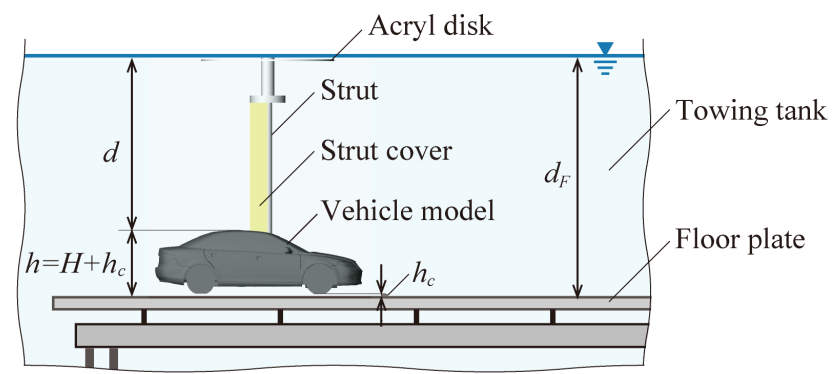

(c) Schematic view of experimental setup

Fig. 4 Schematic views of an experimental model and a measurement system. A six-component load cell was installed in the one-fifth-scale vehicle model, as shown in Figure (b). The model was connected to the sub-carriage through a six-component load cell and a circular strut with an airfoil cover. In the present configuration, the parameters $F r_{d}$ defined in Eq. (1) and $d / h$, which are related to the free surface effect, are set to be 0.34 and 2.6, respectively. These values satisfied the conditions $F r_{d}<$ 0.37 and $d / h>2.0$ to make the influences of the water surface on the fluid force negligible (Kanai, et al., 1991).

\section{$3 \cdot 3 \cdot 2$ 試験条件}

試験条件として，はじめに車両進行速度 $U$ に相当する曳航速度について述べる. 自由表面近くを進行する物体 には，物体周囲の流れと自由表面との干渉が生じ，自由表面の造波現象も伴うことで，無限流体中を進行する場 合とは異なる流体力が作用する．金井ら(金井他，1991)は，曳航水槽中の仮底平板上で 1/5 スケールのセダン型乗 
Nakashima, Tsubokura, Okada, Nouzawa, Mizokane and Doi,

Transactions of the JSME (in Japanese), Vol.80, No.818 (2014)

用車模型を曳航し，曳航条件と自由表面影響との関係について調査した。 その結果，乗用車模型の抗力および揚 力に対する自由表面影響は, 模型の没水深さ $d$, 芈航時の模型全高 $h$ および曳航速度 $U$ から定まる 2 つのパラメ 一タ $d / h, F r_{d}$ に依存し，それぞれ $d / h>2.0, F r_{d}<0.37$ を満足する条件下であれば, 模型に作用寸る流体力におけ る自由表面影響が十分小さくなることを報告している．ここで，Fr

$$
F r_{d}=\frac{U}{\sqrt{d g}}
$$

で定義され， $h, d$ につては図 4 中に図示した通りである. そこで本研究では, 上記の条件を満足するよう曳航 速度 $U$ を $0.9 \mathrm{~m} / \mathrm{s}$ に設定した. また，タイヤ下面の仮底平板からの高さ $h_{c}$ は $0.005 \mathrm{~m}$ とし，模型の没水深さ $d$ を $0.72 \mathrm{~m}$ とした. これによりパラメータ $d / h$ および $F r_{d}$ はそれぞれ $2.5,0.34$ となり，いずれも金井らによる条件を 満足することから，自由表面影響については十分小さいものとみなして計測を実施した．なお，実験時の平均水 温は $8.5^{\circ} \mathrm{C}$ であり, 曳航速度と純水物性, および模型全長に基づく Reynolds 数は $6.0 \times 10^{5}$ である.

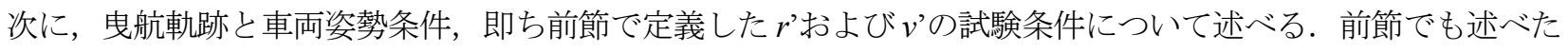
通り, 本論文では車両の鉛直方向姿勢変化を無視することとし, 一定の $r^{\prime}, v^{\prime}$ のを強制的に模型車両に与えるこ ととした. 寸なわち, 実際に旋回走行する自動車において生じる空力現象のうち, 鉛直方向の姿勢変化や水平面 内の非定常的な運動による空力特性一の影響についてはこれらを排除し，定常的な水平面内運動の影響によって 生じる空力特性を計測した. 両パラメータの設定にあたっては, 岡田ら(岡田他, 2014)による実車蛇行走行試験 において計測された車両運動を参考に，その計測範囲を決定した。同実車走行試験では， $120 \mathrm{~km} / \mathrm{h}$ 走行時の車両 に ISO のテスト手法(ISO13674-1, 2010)に準じた正弦波状の操舵入力を与え, 図 5 の概念図に示寸ような蛇行軌跡 で車両が走行した際の車両運動が計測されている. 同試験における操舵入力の周波数は $0.2 \mathrm{~Hz}$, 横方向加速度の 最大值は $2.0 \mathrm{~m} / \mathrm{s}^{2}$ であり, これらは一般的な走行状態（佐藤他，1990）と同程度であることから, 計測された車両 運動パラメータも一般的な旋回走行において生じうる值と考えられる. 計測された旋回角速度は横変位が最大と なる軌跡の山と谷の頂点近傍で絶対值が最大となり, その值は $\left|r^{\prime}\right|=0.0076$ であった. また，すべり角 $\beta$ も蛇行軌 跡の頂点（図中(B)と(D)）において絶対值が最大となり，その值は $|\beta|=0.24^{\circ}=0.0042 \mathrm{rad}$ であった. これを無次元 横すべり速度に換算すると, $\left|v^{\top}\right|=0.0042$ に相当する. ただし, 図に示すように蛇行軌跡の頂点において車両は軌 跡の接線の内側を向いており, 旋回角速度とす心゙り角は互いに逆向きである. このため, 蛇行軌跡の頂点におい て $r^{\prime}$ と $\beta$ は異符号であり, $v^{\prime}$ もた $r^{\prime}$ と異符号となっている.

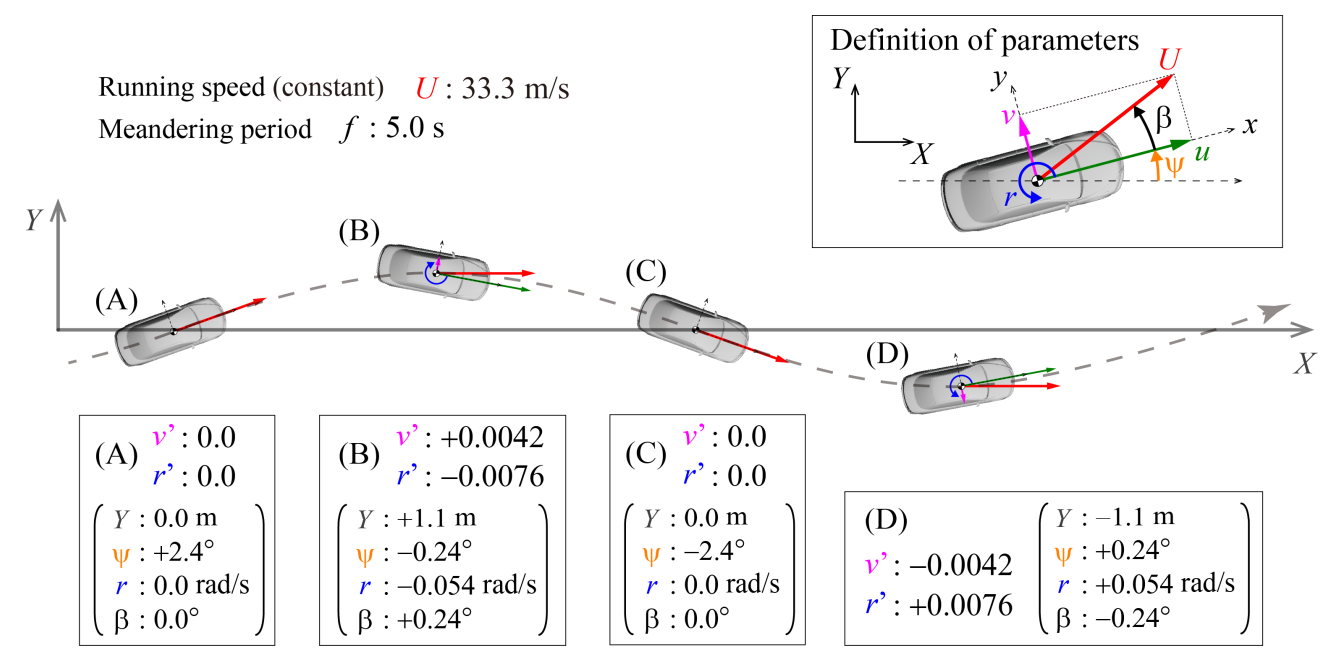

Fig.5 Schematic view of an on-road measurement conducted by Okada et al. (Okada, et al., 2014). The vehicle drew a sinusoidal trajectory, and its motion parameters at Points (A) to (D) are shown in the boxes. At Points (B) and (D), which are the rightand left-turning peaks of the trajectory, the nondimensional yaw rate and lateral velocity show their maximum magnitudes, although they have opposite signs. 
以上の岡田らによる実走試験計測結果を基に，本研究での計測条件として $r^{\prime} に は ~ 0, \pm 0.0075, \pm 0.015, \pm 0.030$ の 7 条件を設定した. これらを実車寸法の旋回半径 $R$ に換算寸ると, それぞれ $0,620 \mathrm{~m}, 310 \mathrm{~m}, 160 \mathrm{~m}$ となる. また, $v^{\prime} に$ 関しては模型回転軸位置 $x=x_{b}$ におけるすべり角 $\beta_{b}$ が $0, \pm 0.5^{\circ}, \pm 1.0^{\circ}$ となる 5 条件を設定した. ただ し，座標原点における横方向速度は旋回角速度に伴って $v=v_{b}+r x_{b}$ となるので, $r^{\prime}$ に応じて $v^{\prime}$ の設定值は変化す

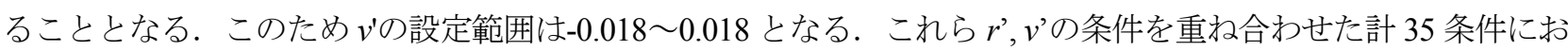
いて計測を行った. また, $r^{\prime}=0$ の場合に限っては上記条件に加えて $\beta$ が $\pm 1.5^{\circ}, \pm 2.0^{\circ}$ の 4 条件でも計測を行った.

\section{$3 \cdot 3 \cdot 3$ 計測結果の処理}

曳航水槽試験では，静止状態から模型を加速し，模型が仮床上において設定曳航速度での定常曳航状態に達し て，計測流体力が安定した後から，10 秒間， $9 \mathrm{~m}$ を計測区間とする流体 6 分力の計測を行った．なお，各計測条 件について，それぞれ 1 回の試験を実施した. 図 6 に曳航中に 6 分力計により計測された流体力の時系列データ を例示寸る. グラフは $r^{\prime}=-0.03, v^{\prime}=-0.0026$ の条件で計測された $x, y$ 軸方向の力 $F_{x}, F_{y}$ と $z$ 軸周りのモーメント $M_{z}$ を示しており, 計測データを薄線で, 0.1 秒間の移動平均を施したデータを太実線で, それぞれ示している.

なお，旋回角速度を伴う計測では，車両模型が向心方向に加速度をもつため，計測される力とモーメントには 模型自身の慣性の影響が含まれる. そこで，模型（6 分力計内蔵スペース内の水塊を含む）の質量と重心位置を 計測し, 模型の速度と角速度を基に遠心力を算出して, 計測された横力とヨーモーメントの時間平均值から, そ れぞれ減算することで各流体力を抽出した.



Fig.6 Time series of fluid-dynamic forces in longitudinal and lateral directions $F_{x}$ and $F_{y}$ and moment around a vertical axis $M_{z}$ acting on the vehicle model measured in the towing tank experiment $\left(r^{\prime}=-0.03, v^{\prime}=-0.0026\right)$. Profiles of the raw data (translucent lines) and the 0.1-s moving average (thick solid lines) are drawn in the graph. Black, red, and blue colors mean $F_{x}, F_{y}$, and $M_{z}$, respectively. The measurement period was $10 \mathrm{~s}$ while the model was steadily towed above the temporal floor plate. Forces and moments shown in a later section are the averaged value in this measurement period.

また, 計測結果の流体力 $F$ および流体力モーメント $M$ は無次元化し, 無次元係数として整理した. 流体力係数 $C_{F}$ および流体力モーメント係数 $C_{M}$ は， $F$ および $M$ に対して，それぞれ以下のように定義した.

$$
\begin{aligned}
& C_{F}=F /\left(\frac{1}{2} \rho U^{2} A\right) \\
& C_{M}=M /\left(\frac{1}{2} \rho U^{2} A L_{w}\right)
\end{aligned}
$$

なお，本稿では， $x$ 軸負方向の抗力 $-F_{x}, y$ 軸方向の横力 $F_{y}$, 前後輪軸位置に作用寸る $z$ 軸方向の揚力 $F_{z f}, F_{z r}$, お よび $z$ 軸周り回転方向のヨーモーメント $M_{z}$ に対する係数を, それぞれ抗力係数 $C_{D}$, 横力係数 $C_{S}$, 前後輪軸位置 における揚力係数 $C_{L}, C_{L r}$, およびヨーモーメント係数 $C_{Y M}$ と呼称することとする. 
Nakashima, Tsubokura, Okada, Nouzawa, Mizokane and Doi,

Transactions of the JSME (in Japanese), Vol.80, No.818 (2014)

\section{4. 試験結果と考察}

\section{$4 \cdot 1$ 直進時及び横すべり運動による発生流体力}

計測手法の基礎検証のために，風洞実験が可能な，車両のヨー回転運動を考慮しない直進すべり走行時の運動 を対象とした計測結果を示す (図 2 (b)の車両運動軌跡が直線の場合). 即ちここでは, $r^{\prime}=0$ とし, 横すべり速度 v’をパラメータとする。これは自動車が定常的な横すべりを伴いながら一定速度で直進走行する状態である。こ こでは，対象車両モデルの流体力特性を確認するとともに，対象模型の原型であるセダン型乗用車の実車風洞試 験結果(岡田他，2014)を参考值として，本研究における車両模型を用いた曳航水槽試験の妥当性を検証する.

まず, 直進状態 $\left(r^{\prime}=v^{\prime}=0\right)$ の流体力特性として, 表 1 に各流体力係数を示寸. 車両形状や地面条件, Reynolds 数などが異なるものの，抗力係数に関しては実車風洞条件とほぼ同等の值を示しており，セダン型自動車を模し た形状として，その流体力特性も再現されていることを示している，一方，揚力係数については，特に前輪軸位 置での揚力係数 $C_{L f}$ に符号の逆転が生じている．この要因としては，風洞試験では地面と車両の相対速度が考慮 されていないため床下流入流速が少なく, 床下圧力の低下が少ないと考えられること，曳航水槽試験ではタイヤ 部が地面に接地しておらずタイヤ下で縮流による負圧が作用すると考えられること，および，模型支持のための ストラットにより車両上面前方の圧力が増大しうることが挙げられる.

Table 1 Aerodynamic coefficients measured in a straight towing condition. The coefficients measured in the current towing tank experiment are compared with the previous wind tunnel experiment of a real sedan-type vehicle (Okada, et al., 2014). The present experimental model shows similar aerodynamic characteristics of the real vehicle, although the $C_{L f}$ has a different sign because of the different conditions of the ground, tires, and strut from the wind tunnel experiment.

\begin{tabular}{|r|c|c|c|c|c|}
\hline & $C_{D}$ & $C_{L f}$ & $C_{L r}$ & $C_{S}$ & $C_{Y M}$ \\
\hline $\begin{array}{r}\text { Present towing tank experiment } \\
\text { (A simplified one-fifth-scale model) }\end{array}$ & 0.346 & -0.106 & 0.149 & 0.044 & -0.003 \\
\hline $\begin{array}{r}\text { Wind tunnel experiment (Okada, et al., 2014) } \\
\text { (A real sedan-type vehicle) }\end{array}$ & 0.32 & 0.09 & 0.11 & 0.00 & 0.00 \\
\hline
\end{tabular}

次に，横すべり運動に伴って生じる車両への作用流体力の変化について図 7 に示す. グラフはすべり角 $\beta$ に対 する横力係数およびヨーモーメント係数の直進状態からの恋化量 $\Delta C_{S}, \Delta C_{Y M}$ を示している.

図 7 のグラフが示すように，すべり角が正側へ変化するに伴い，横力係数，ヨーモーメント係数はともに負側 へと值が変化する. 即ち, 車両が左斜め前方へ進行する場合に，車両右向きの横力と車両を右旋回方向へ回転さ
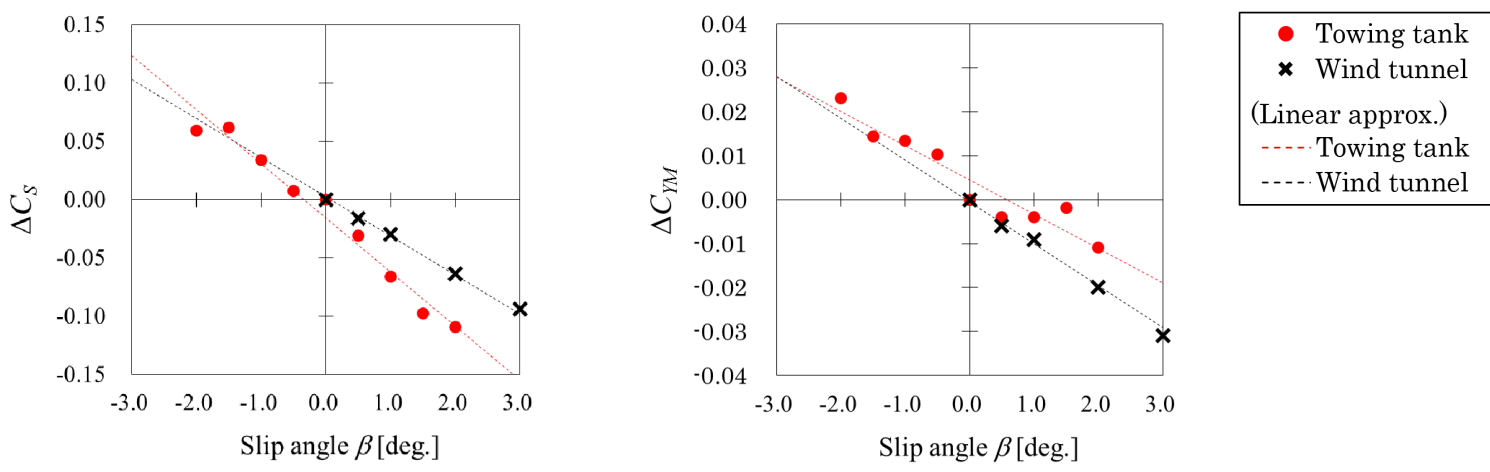

Fig.7 Dependencies of variations of side force coefficient $\Delta C_{S}$ (left) and yaw moment coefficient $\Delta C_{Y M}$ (right) on a slip angle $\beta$. Measurement results of the current towing tank experiment with the one-fifth-scale simplified model are compared to the previous wind tunnel experiment (Okada, et al., 2014) with the real sedan-type vehicle. Aerodynamic characteristics of the real vehicle in horizontal motions was successfully simulated by the current towing tank experiment because the variations show a similar tendency and their gradients $\Delta C_{S} / \beta$ and $\Delta C_{Y M} / \beta$ of the current experimental model are 1.4 times and 0.8 times those of the real vehicle, respectively. 
Nakashima, Tsubokura, Okada, Nouzawa, Mizokane and Doi,

Transactions of the JSME (in Japanese), Vol.80, No.818 (2014)

せるヨーモーメントが発生している。このような発生流体力の傾向は，一様流中で迎角を与えられた翼型などの 細長物体に作用する揚力およびピッチングモーメントと同じであり，実車風洞試験結果とも定性的に一致してい る. また, 実車風洞試験との定量的比較においても, すべり角の変化に対する横力係数の傾斜が約 1.4 倍, ヨー モーメント係数の傾斜は 0.8 倍程度であり, 一部境界条件や Reynolds 数条件が異なるものの同オーダの值を示し ている.このことから，本研究における $1 / 5$ スケール車両モデルを用いた曳航水槽模型試験は水平面内運動する セダン型乗用車の空気力学的特性を模擬しており, 本試験による車両空力特性の検討の妥当性が示されている.

\section{$4 \cdot 2$ 旋回運動時に発生する流体力}

\section{$4 \cdot 2 \cdot 1$ 発生流体力特性}

本節では，定常円旋回運動時に発生する流体力について述べる. 3 ・3 節に示したヨー回転運動と横すべり運動 を伴う計 35 条件の曳航試験により計測された, 横力係数およびヨーモーメント係数の直進状態 $\left(r^{\prime}=v^{\prime}=0\right)$ から の変化量 $\Delta C_{S}, \Delta C_{Y M}$ を図 8 に示寸. 図 8 は, 横軸に無次元横すべり速度 $v^{\prime}$ をり, 旋回角速度 $r^{\prime}$ に応じた色分け をして計測值をプロットしたグラフである. また，同グラフ中には重回帰分析により求めた線形近似多項式に基 づく $\Delta C_{S}, \Delta C_{Y M}$ の近似直線も併せて示した．計測結果の重回帰分析については $4 \cdot 2 \cdot 3$ 項において後述する. な お，3.2.節で述べたように $U \gg v ，$ すなわち $1 \gg v$ であれば， $\beta \fallingdotseq v$ という近似が成り立つので，同グラフの横軸は 近似的にすべり角 $\beta$ とみなすことができる，この近似は，以降の $v^{\prime}$ と発生流体力の関係に関する議論においても 有効である. ただし，このときのすべり角の単位は，図 7 中のグラフに示した度ではなく, ラジアンであること に注意されたい.

図 8 のグラフが示すように, $r^{\prime}$ の值の正側への変化に伴って横力係数の值は正側へ, ヨーモーメント係数の值 は負側へと，それぞれ変化している．これは自動車が左旋回（ $r^{\prime}>0 ）$ することにより, 左向きの横力と, 旋回方 向とは反対の右旋回向きに車両を回転させようとするヨーモーメントが作用することを意味する．また，すべて の $r^{\prime}$ において，横すべり速度 $v^{\prime}$ に対する横力とヨーモーメントの変化は同じ傾向を示しており，これは $r^{\prime}=0$ の 直進時とも同じ傾向である.

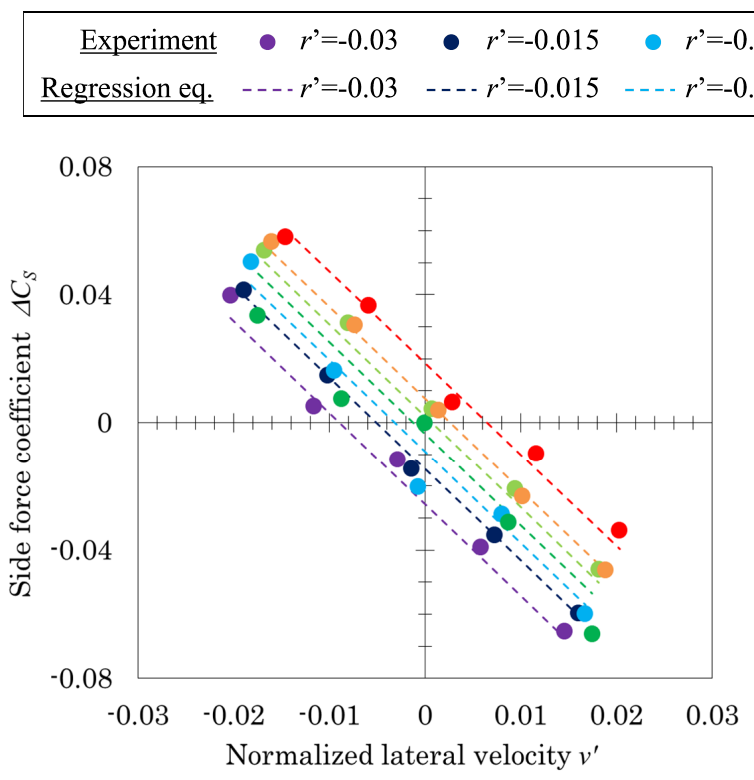

(a) Side force coefficient

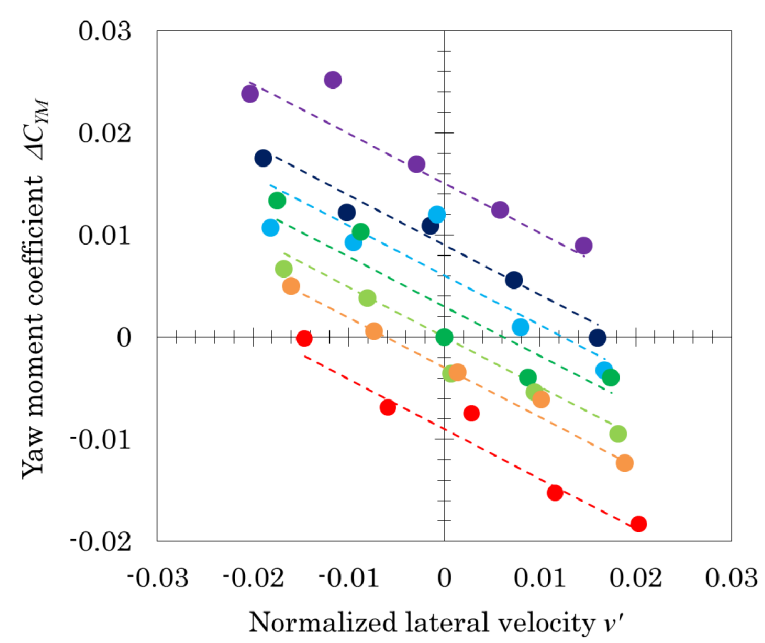

(b) Yaw moment coefficient

Fig.8 Variations of side force and yaw moment coefficients $\Delta C_{S}$ and $\Delta C_{Y M}$ depending on a combination of the yaw rate $r$ ' and side slip velocity $v^{\prime}$. Dashed lines are the approximated linear function given by a multiple regression analysis, which is described in paragraph $4 \cdot 2 \cdot 3$. With a positive change of $r^{\prime}, C_{S}$ and $C_{Y M}$ change to positive and negative sides, respectively. This fact means that the side force to the left side $\left(C_{S}>0\right)$ and the yaw moment opposed to the yaw rotation $\left(C_{Y M}<0\right)$ act to the vehicle turning left $\left(r^{\prime}>0\right)$. At all $r^{\prime}$ conditions, dependencies of $C_{S}$ and $C_{Y M}$ on the lateral velocity show a similar tendency. 
Nakashima, Tsubokura, Okada, Nouzawa, Mizokane and Doi, Transactions of the JSME (in Japanese), Vol.80, No.818 (2014)

\section{$4 \cdot 2 \cdot 2$ 旋回運動に伴う流体力の発生要因分析}

前項で述べた旋回運動時の自動車に作用寸る流体力について，その発生要因を考察し，それぞれの流体力特性 を踏まえた上で，図 8 の曳航試験結果を分析する，考察にあたっては，船舶運動力学における流体力についての 知見(元良，1955)を参考とした.

旋回運動時の車両に横力を発生させる要因としては，風洞実験等で既に検討されているすべり運動の影響の他 に, 旋回運動特有の要因として, 車両の自転運動に伴う車両周りの循環の発生と, 車両重心の円弧運動に伴う向 心方向加速運動が考えられる．また，車両の自転運動によって車両局所における周囲流体との相対速度が変化す るので，それに伴って車両局所に作用する非定常渦放出に伴う流体力と摩擦による流体力（以降，それぞれを渦 抵抗力, 摩擦力と称する）も変化し, それらの流体力の車両横方向成分も横力を生じると考えられる. そこで, 以上 3 つ横力発生要因について考察する.

自転運動によって生じる循環 $\Gamma$ はマグヌス効果と類似の効果を生じ，地面に平行，かつ車両重心から見た一様 流に対して垂直方向に力を発生するので，この分力が横力を生む. 例えば図 2 (b)の左旋回時は $y$ 軸正の車両左向 きに横力が発生する. ポテンシャル理論からの類推からこの力は角速度 $r$ に比例し, また回転物体の物体表面積 と回転軸周りの物体の代表長さとも比例関係にあると考えられる．したがって車両正面投影面積と車長を用いれ ば，自転運動に伴う横力 $F_{y M}$ は

$$
F_{y M}=\rho U \Gamma=C_{\Gamma} A L \rho U r
$$

と見積もられる． $C_{\Gamma}$ は車両形状に依存し，特異な場合を除いて正值をとると考えられる定数である.

一方，流体中で物体が加速運動をする場合には，周囲流体を引き連れて加速する必要があるため，その反作用 として加速運動を妨げる方向に流体力が作用する，いわゆる付加質量効果が生じる. 定常旋回運動では車両は向 心方向に加速運動しているため, 付加質量効果によって旋回運動の遠心力方向に流体力が生じ, その分力として 横力が発生する. 旋回運動する物体の横方向に作用する遠心力成分 $F_{y A}$ は, 物体前後方向の加速運動により生じ る付加質量 $m_{x}$ に依存寸る(元良, 1955 )ことが知られている. また， $m_{x}$ は物体形状に依存し，物体体積と周囲流体 密度にも比例するので，物体体積を車両正面投影面積と車長の積で評価すると， $F_{y A}$ は

$$
F_{y A}=-m_{x} U r=-C_{A M} \rho A L U r
$$

と見積もられる．ここで， $C_{A}$ もた，車両形状に依存し，正值をとる定数である.

最後に, 車両の自転運動に伴う車両局所の相対流速変化によって生じる渦抵抗力および摩擦力の変化の影響に ついて考察する.ここでは, 一般的な自動車の走行条件は高 Reynolds 数流れであることを考慮し, 摩擦力の影響 は渦抵抗力に比べて微小であるものとして，渦抵抗力についてのみ考察することとする. 物体局所に生じる渦抵 抗力が物体の影響を排した局所相対流速によって決定されるものと仮定した考察(元良, 1955)の，r’1 における 評価では，自転運動に伴う渦抵抗力変化が生じる横力 $F_{y V}$ は， $L ， u$ ，および $r$ に比例することが示されている. そこで， $u \fallingdotseq U$ と近似し，同横力が物体表面積と周囲流体密度とも比例関係にあるとすれば， $F_{y V}$ は

$$
F_{y V}=C_{F V} \rho A L U r
$$

と見積もられる．ここで， $C_{F V}$ は車両局所からの渦放出による抵抗特性を表寸係数である，なお，自転運動によ る横方向の相対流速変化は，自転運動の中心となる重心点の前後においてその向きが逆転し，それに伴う渦抵抗 力も重心点の前後で互いに打ち消しあうので, $C_{F V}$ の值とその正負は車両形状, 特にその重心軸に対寸る非対称 性に依存するものと考えられる．また，その大きさに関して，回転抵抗計測用の模型船舶(赤崎他，1942)に対す る見積もり(元良, 1955)では, 船首および船尾部が生じる自転運動に伴う渦抵抗力の大きさが, 自転運動の循環 によって生じる横力の 2 5 割程度と見積もられている. 自動車においても, 重心の前側と後側でそれぞれ同オー ダの横力が逆向きに発生するとすれば, 両者の差分となる渦抵抗力による横力の大きさは, 循環により生じる横 力に比べて充分小さくなり， $C_{\Gamma} \gg\left|C_{F}\right|$ であると考えられる. 
Nakashima, Tsubokura, Okada, Nouzawa, Mizokane and Doi,

以上より， $F_{y M}, F_{y A}$ および $F_{y A}$ の合力 $F_{y T}$ は，式(4)〜(6)をそれぞれ足し合わせて

$$
F_{y T}=F_{y M}+F_{y A}+F_{y V}=\left(C_{\Gamma}-C_{A M}+C_{F V}\right) \rho A L U r \approx\left(C_{\Gamma}-C_{A M}\right) \rho A L U r
$$

となり,これらの効果を合わせた横力の作用方向は, 最終的に $\left(C_{\Gamma}-C_{A M}+C_{F V}\right)$ の符号, 近似的には $\left(C_{\Gamma}-C_{A M}\right)$ の 符号によって決定されることがわかる. 従って, 各係数の值が車両形状のみで決まるものであれば, この横力は 旋回方向に対して常に一定の向きに作用寸る. また，上記の要因に基づいて評価される横力係数 $C_{S, E}$ は，式(7)の $F_{y T}$ を無次元化して,

$$
C_{S, E} \approx\left(C_{\Gamma}-C_{A M}\right) \rho A L U r /\left(\frac{1}{2} A \rho U^{2}\right)=2\left(C_{\Gamma}-C_{A M}\right) r^{\prime}
$$

となるので，ここまでに述べた仮定に基づけば，横力係数は無次元旋回角速度 $r^{\prime}$ に比例するものと考えられる.

以上の議論を基に, 前項に示した横力の計測結果を分析する. 図 8 (a)において, $r^{\prime}$ に対する $C_{S}$ の変化の傾向に 注目すると, $r^{\prime}$ の值の正側への変化（寒色のプロットから暖色のプロットへかけての変化）に伴って $C_{S}$ の值も正 側へと変化している. これは, 図2(a)における反時計周りの回転角速度の発生に伴って $y$ 軸正の方向の向心力が 発生することを意味する，従って，先の仮定が成立する範囲内であれば，対象車両モデル形状には旋回運動に伴 う車両の回転運動に起因して, 常に向心方向の流体力が作用することとなる. また, $r^{\prime} に$ 対する $C_{S}$ の変化を式(8) の $r^{\prime}$ と $C_{S, E}$ との比例関係に対応付けると, 係数 $2\left(C_{\Gamma}-C_{A M}\right)$ は正となり, $C_{\Gamma}>C_{A M}$ と考えられる. 即ち, 定常円旋 回する自動車に作用する横力については，ここで議論した 3 要因のうち，車両の自転運動に伴う循環が発生する 横力が卓越しているものと考えられる，ただし， $C_{\Gamma}$ や $C_{F V}$ の值は，車両局所が生じる剥離流れの性状などによっ て変化し, 害際には $r$ やUに依存するものと考えられるので, これらの依存性については今後検討が必要である.

次に，旋回運動する車両にヨーモーメントを発生する流体現象について考察する．ここでは，先の横力に関す る議論で述べた旋回運動特有の 3 つの流体力発生要因に注目し, それぞれに起因寸るヨーモーメントについて評 価することとする.

自転運動に伴う循環の影響について，マグヌス効果と類似の効果によって発生する横力 $F_{y M}$ は，座標原点であ る車両重心回りにヨーモーメント

$$
M_{z M}=F_{y M} x_{M}=C_{\Gamma} x_{M} A L \rho U r
$$

を生じる．ここで， $x_{M}$ は循環の影響により発生するヨーモーメントがゼロとなる車両前後軸上の点の $x$ 座標であ る. 以降この点を単に，圧力中心と称することとする，一方，付加質量効果に関しては，定常円旋回運動では角 加速度が 0 であるので付加慣性モーメントについて考慮する必要は無い. 従って, 同効果により発生するヨーモ 一メントは, 先の自転運動に伴う循環の影響と同様, 付加質量効果による遠心力方向の流体力の分力として生じ る横力 $F_{y A}$ とその圧力中心の $x$ 座標 $x_{A}$ によって

$$
M_{z A}=F_{y A} x_{A}=-C_{A M} x_{A} \rho A L U r
$$

と表すことができる．以上の 2 つの発生要因によるヨーモーメントが作用する向きについては，横力 $F_{y M}, F_{y A}$ と は異なり, $x_{M}, x_{A}$, 即ち各々の圧力中心位置と重心との前後位置関係が物体形状に依存すると考えられるため, その評価は困難である.これに対して車両の自転運動に伴う車両局所の相対流速変化で生じる渦抵抗力変化の影 響については，当然ながら車両局所の相対流速が自転速度の逆向きに変化するので，その渦抵抗力も自転運動之 逆向きのヨーモーメントを発生すると考えられる. 横力と同様に $r^{\prime} \ll 1$ における評価(元良, 1955)を参考にすると， そのヨーモーメント $M_{z V}$ は $L^{2}, u$, および $r$ に比例するものとされている. ここでは, 車両面積と周囲流体密度の 影響も考慮して, $M_{z V}$ を 
Nakashima, Tsubokura, Okada, Nouzawa, Mizokane and Doi,

$$
M_{z V}=-C_{M V} \rho A L^{2} U r
$$

と評価することとする，ここで， $C_{M V}$ は車両からの渦放出による抵抗特性を表す係数であり，車両形状に依存す るものと考えられる．自転運動に伴う局所相対流速変化は常にその運動に対して反対向きであることを考慮する と， $C_{M V}$ は正值を取るものと考えられる.

ここまでに議論した 3 つの発生要因によるヨーモーメント $M_{z M}, M_{z A}, M_{z V}$ の和 $M_{z T}$ は, 式(9)〜(11)より

$$
M_{z T}=M_{z M}+M_{z A}+M_{y V}=\left(C_{\Gamma} x_{M}-C_{A M} x_{A}-C_{M V} L\right) \rho A L U r
$$

となり, これらの効果を合わせたヨーモーメントの作用方向は, 最終的に $\left(C_{\Gamma} x_{M}-C_{A M} x_{A}+C_{M V} L\right)$ の符号により 決定されることがわかる. 従って, 各係数の值が車両形状のみで決まり, かつ循環と付加質量による影響で生じ るヨーモーメントの圧力中心位置についても車両形状のみに依存すると仮定すれば，定常円旋回時に生じるヨー モーメントは，旋回方向に対して常に一定の向きに作用寸ることとなる. また，上記の 3 要因に基づいて評価さ れるヨーモーメント係数 $C_{Y M, E}$ は, 式(12)の $M_{z T}$ を無次元化して，

$$
C_{Y M, E}=\left(C_{\Gamma} x_{M}-C_{A M} x_{A}-C_{M V} L\right) \rho A L U r /\left(\frac{1}{2} A \rho U^{2} L_{w}\right)=\frac{2\left(C_{\Gamma} x_{M}-C_{A M} x_{A}-C_{M V} L\right)}{L_{w}} r^{\prime}
$$

となるので，上記の近似評価に基づけば，ヨーモーメント係数も無次元旋回角速度 $r$ に比例すると考えられる. 以上の議論を基に，前項に示したヨーモーメントの計測結果を分析する．横力の議論と同様に，図 8 (b)におい て $r^{\prime}$ に対寸る $C_{Y M}$ の変化の傾向に注目寸ると, $r^{\prime}$ の值の正側への変化に伴い $C_{Y M}$ は負側へと変化している. これ は, 図2(a)における反時計周りの回転角速度の発生に伴って時計回りのヨーモーメントが発生することを意味し ている. さらに，各係数と圧力中心位置が車両形状のみに依存するという先の仮定が成り立つ範囲であれば，対 象車両モデル形状には，旋回運動に伴う車両の回転運動に起因して，常にその自転運動を妨げる向きのヨーモー メントが作用することとなる. また, $r^{\prime}$ に対する $C_{Y M}$ の変化を式(13)の $r^{\prime}$ と $C_{Y M, E}$ との比例関係に対応付けると, $\left(C_{\Gamma} x_{M}-C_{A M} x_{A}-C_{M V} L\right)<0$ となるが, 車両形状とその発生メカニズムから圧力中心位置 $x_{M}, x_{A}$ は車両上に存在して $\left|x_{M}\right|,\left|x_{A}\right|<L$ と考えられること, 横力に関する議論から $\left|C_{\Gamma}\right|>\left|C_{A M}\right|$ であったこと, 同じく $C_{M V}$ については $C_{\Gamma}$ と同才 一ダと考えられること, などを考慮すると, その要因としては- $C_{M V} L$ の寄与が大きいと考えられる. 即ち, ヨー モーメントの発生においては, ここで議論した 3 要因のうち自転運動に伴って生じる渦抵抗力の影響が卓越して いるものと考えられるが，詳細については前後端形状の異なる車両を用いた更なる検討が必要である.

\section{$4 \cdot 2 \cdot 3$ 重回帰分析を用いた旋回運動影響の定量評価}

前項における議論では, 旋回運動特有のヨ一回転運動に伴って生じる $C_{S}$ と $C_{Y M}$ について, 近似的には $r^{\prime} に$ 比例 すると考えられることを示した. また, 横すべり運動に伴う $C_{S}, C_{Y M}$ にいて, $\beta$ との比例関係を仮定すること

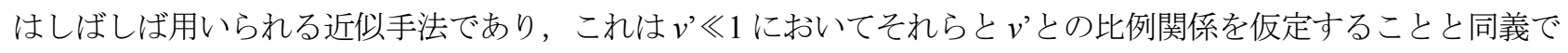
ある.そこでここではまずヨー回転運動と横すべり運動の相互作用については無視して， $C_{S}, C_{Y M}$ が v'と $r^{\prime}$ の線形 多項式

$$
\begin{aligned}
& C_{S}\left(v^{\prime}, r^{\prime}\right)=Y^{\prime}{ }_{v} v^{\prime}+Y_{r}^{\prime}{ }_{r} r^{\prime}+C_{S, 0} \\
& C_{Y M}\left(v^{\prime}, r^{\prime}\right)=N^{\prime}{ }_{v} v^{\prime}+N^{\prime}{ }_{r} r^{\prime}+C_{Y M, 0}
\end{aligned}
$$

によって近似評価できるものと仮定し，その有用性を $4 \cdot 2 \cdot 1$ 項の実験結果より実証する．これにより，両運動 により生じる横力とヨーモーメントの発生量と運動パラメータとの関係について, 重回帰分析を用いて定量的に 
評価することができる．なお，式(14), (15)中の $Y^{\prime}{ }_{v}, Y^{\prime}{ }_{r}, N^{{ }^{\prime}}{ }_{v}, N^{\prime}{ }_{r}$ は，それぞれ $C_{S}$ と $C_{Y M}$ の $v^{\prime}$ と $r^{\prime}$ に対する 1 次の 微係数であり, 横力とヨーモーメントの $v$ と $r$ に対する微係数を次式のように無次元化した無次元係数である.

$$
\begin{aligned}
& Y_{v}^{\prime}=\left(\frac{\partial F_{y}}{\partial v}\right) /\left(\frac{1}{2} \rho U A\right), \quad Y_{r}^{\prime}=\left(\frac{\partial F_{y}}{\partial r}\right) /\left(\frac{1}{2} \rho U A L\right) \\
& N_{v}^{\prime}=\left(\frac{\partial M_{z}}{\partial v}\right) /\left(\frac{1}{2} \rho U A L_{w}\right), \quad N_{r}^{\prime}=\left(\frac{\partial M_{z}}{\partial r}\right) /\left(\frac{1}{2} \rho U A L L_{w}\right)
\end{aligned}
$$

$4 \cdot 2 \cdot 1$ 項に示した 35 条件の曳航試験結果を用いて, 重回帰分析を行って得られた各係数 $Y_{r}{ }^{\prime}, Y_{v}{ }^{\prime}, N_{r}{ }^{\prime}, N_{v}{ }^{\prime}$ と定 数項 $C_{S, 0}, C_{Y M, 0}$ の值を表 2 に示寸. 表中の各係数からも, $4 \cdot 1$ 節および $4 \cdot 1 \cdot 1$ 項において述べた, 定常円旋回 する自動車において，車両の横すべり運動とヨー回転運動に伴って生じる横力とヨーモーメントの特性を確認す ることができる.

横力に関する微係数值より，車体のヨー回転角速度 $r^{\prime}$ に対する横力係数の勾配は正である。これは，左方向一 旋回する $\left(r^{\prime}>0\right)$ 自動車に対して, ヨー回転運動の効果により, $y$ 軸正方向の左向き力, 即ち向心力が発生する ことを意味する. また, 横すべり速度 $v^{\prime}$ に対しては横力係数の勾配が負である. これは, $y$ 軸正方向である左向 きの横すべりを伴って左斜め前方へと進行する自動車に対し, $y$ 軸負方向である右向きの横力, 即ち横すべりを 抑制する向きの力が発生することを示している. また， $3 \cdot 2$ 節で述べたとおり，一定速以上の高速域で定常円旋 回する自動車においては， $r^{\prime} と v ’ の$ 符合が異なるので，車両のヨー回転運動と横すべり運動が生じる横力は同 符号となって，両者は同じ向きに作用する.

ヨーモーメントについては，車体のヨー回転角速度 $r^{\prime}$ に対するヨーモーメント係数の勾配が負である．これは 同じく左方向へ旋回運動する自動車に対して, ヨ一回転運動の効果により, $z$ 軸周り回転の負方向となる右旋回 方向のヨーモーメント, 即ち旋回に伴う自転運動を抑制する向きのモーメントが発生することを意味する.また, 横すべり速度 $v^{\prime}$ に対するヨーモーメント係数の勾配も負である.これは, $y$ 軸正方向である左向きの横すべりを 伴って進行する自動車に対し，右旋回方向のヨーモーメント，即ち横す心゙りが増大する方向へと車両姿勢を変化 させるヨーモーメントが発生することを示している，ヨーモーメントについては，一定速以上の高速域で定常円 旋回する自動車においては異符号の $r$ と $v^{\prime} か ゙$ 生じると, 車両のヨー回転運動と横すべり運動が生じるヨーモーメ ントも異符号となって，互いに打ち消しあう方向へと作用する.

本重回帰分析における重決定係数は， $C_{S}, C_{Y M}$ につてそれぞれ 0.976, 0.962 であり，各比例係数の標準誤差は $Y_{r}{ }^{\prime}$ が 7.5\%, $Y_{v}{ }^{\prime}$ が 2.8\%， $N_{r}{ }^{\prime}$ が 4.9\%， $N_{v}{ }^{\prime}$ が 6.0\%であった。このことから，式(14)，(15)による近似表現と重回帰分

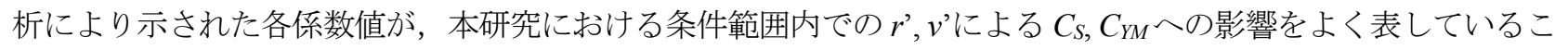
とがわかる.このことは図 8 に示したグラフからも明らかである.

Table 2 Partial derivatives of $C_{S}$ and $C_{Y M}$ with respect to $r$ ' and $v^{\prime}$ estimated by a multiple linear regression analysis based on Eqs. (14) and (15). These derivatives quantitatively show the dependencies of $C_{S}$ and $C_{Y M}$ on $r$ ' and $v$ ' shown in Fig. 8. The approximation equations describe the dependencies well because the coefficients of determination for the multiple linear regression analyses of $C_{S}$ and $C_{Y M}$ are 0.976 and 0.962 , respectively.

\begin{tabular}{|c|c|c|c|c|c|}
\hline \multicolumn{3}{|c|}{$C_{S}$} & \multicolumn{3}{c|}{$C_{Y M}$} \\
\hline$Y_{r}{ }^{\prime}$ & $Y_{v}{ }^{\prime}$ & $C_{S, 0}$ & $N_{r}{ }^{\prime}$ & $N_{v}{ }^{\prime}$ & $C_{Y M, 0}$ \\
\hline 0.74 & -2.9 & 0.0404 & -0.40 & -0.49 & -0.00035 \\
\hline
\end{tabular}




\section{$4 \cdot 2 \cdot 4$ 高速操舵走行条件における発生流体力の準定常的評価}

前項で得られた，ヨー回転運動および横すべり運動に伴って生じる，横力およびヨーモーメント係数の変化を 表す線形近似多項式を用いて，高速操舵走行する実車に発生する流体力変化について評価を試みる．なお，ここ で用いる線形近似多項式は，本研究で実施した曳航水槽実験による定常旋回運動に伴って発生する定常流体力か ら導かれたものであるので，その評価は準定常的であることに注意されたい. 実車による高速蛇行走行試験(岡田 他，2014)において計測された車両運動パラメータ $r^{\prime}, v^{\prime}$ は，いずれも横変位が最大となる蛇行軌跡の頂点で最大 最小值をとるが, $r^{\prime}$ と $v^{\prime}$ は逆位相であり, 蛇行軌跡の頂点では $\left(r^{\prime}, v^{\prime}\right)$ は左旋回側で $(0.0076,-0.0042)$, 右旋回側で $(-0.0076,0.0042)$ の組合せであった． そこで，表 2 の係数值と，蛇行軌跡の左旋回側の頂点におけるパラメータ の值 $\left(r^{\prime}, v^{\prime}\right)=(0.0076,-0.0042)$ を, 式(14), (15) 一代入し，実走行状態において準定常的に発生する旋回と横すべり に伴う横力とヨーモーメント係数の推定変化量を評価した。 その結果を表 3 に示す.

表より，横力については，横すべり運動に伴う横力係数変化 $Y_{v}{ }^{\prime} v^{\prime}$ に対して，ヨ一回転運動に伴う横力係数変化 $Y_{r}^{\prime} r^{\prime}$ は約 0.5 倍となっており，蛇行運動の最大横変位の位置では，横すべり運動による横力への影響が旋回運動 による影響を上回っていることが予想される．また，両運動は同方向に横力を発生している．しかし，発生横力 の定量評価においては，回転運動に伴う横力係数の変化も無視できない大きさを有することが示されている．一 方, ヨーモーメントについては, ヨー回転運動に伴う係数変化 $N_{r}{ }^{\prime}{ }^{\prime}{ }^{\prime}$ が横す心゙り運動に伴う係数変化 $N_{v}{ }^{\prime} v^{\prime}$ に対し て約 1.5 倍であり，旋回運動の寄与が横すべり運動のそれを上回っている．加えて，両成分の符号が異なること から両者は互いに逆方向にヨーモーメントを生じており，その効果を打ち消し合うことがわかる．このことは， モーメントが生じる向きを検討するような定性的評価においても，ヨー回転運動による寄与を考慮する必要があ ることを示している.

Table 3 Variation of $C_{S}$ and $C_{Y M}$ in a typical on-road condition estimated by Eqs. (14) and (15). Values of the parameters $\left(r^{\prime}, v^{\prime}\right)=$ $(0.0076,-0.0042)$, which are measured at the left-turning peak of the trajectory in the on-road measurement (Okada, et al., 2014), are substituted in the equations. The effects of yaw rotation described as $Y_{r}^{\prime} r^{\prime}$ and $N_{r}^{\prime} r^{\prime}$ have considerable magnitudes. This indicates a need to consider these effects in the consideration of vehicle aerodynamics in steady-state cornering.

\begin{tabular}{|c|c|c|c|}
\hline \multicolumn{2}{|c|}{$\Delta C_{S}$} & \multicolumn{2}{c|}{$\Delta C_{Y M}$} \\
\hline$Y_{r}{ }^{\prime} r^{\prime}$ & $Y_{v}{ }^{\prime} v^{\prime}$ & $N_{r}{ }^{\prime} r^{\prime}$ & $N_{v}{ }^{\prime}{ }^{\prime}$ \\
\hline 0.0056 & 0.0121 & -0.0030 & 0.0020 \\
\hline
\end{tabular}

\section{5. 結 言}

曳航水槽を用いた検力試験を行って，定常円旋回時の自動車に作用寸る空気力とその発生メカニズムを調査し た．定常円旋回時の自動車の運動を，車両重心を原点とする自動車固定の座標系で定義された車両のヨー回転運

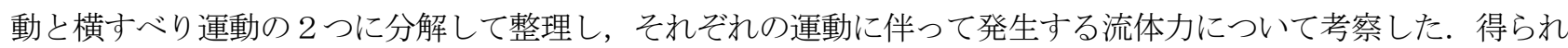
た結果に対して, 発生流体力がヨー回転角速度と横すべり速度との線形和で表現できるものと仮定し，その線形 係数を重回帰分析により求めた．その結果，以下のことが明らかとなった.

(1) 本研究における計測範囲では，発生流体力に対する車体のヨー回転運動と横す心゙り運動の影響が，両者の 線形の重㸚合わせで説明できることが明らかとなった。

（2）横力については，図 9 に示すように，車両のヨー回転運動により円弧軌道に対する向心力が，横すべり運 動により横すべりを抑制する向きの力が，それぞれ発生する。一般的な自動車の走行条件では，車両重心の横す べりは旋回円に対して外向きである（即ち，車両は旋回円の内側を向いている）ことが多く，このことを考慮す ると，横すべり運動に伴って生じる空気力も向心方向に作用すると考えられる.

（3）ヨーモーメントについては，図９に示すように，車体のヨー回転運動によりその回転を抑制する向きのモ 一メントが，横す心゙り運動により横すべりを増大する向きに車体の姿勢を変化させるモーメントが，それぞれ発 
Nakashima, Tsubokura, Okada, Nouzawa, Mizokane and Doi,

Transactions of the JSME (in Japanese), Vol.80, No.818 (2014)

生する. したがって一般的な自動車の走行条件では，両モーメントは互いに打ち消しあう方向に作用すると考え られる。

（4）セダン型乗用車による蛇行運動試験で観測された車両の回転角速度と横速度から, 準定常的な空気力を予 測評価したところ, 横変位が最大となる場所での空気力は, 横力, ヨーモーメント共にヨー回転運動の影響と横 すべり運動の影響は同オーダであった，横力については，回転運動の影響が横すべり運動の影響の 5 割程度の大 きさを示し，ヨーモーメントについては，ヨー回転運動の影響が横すべり運動の影響の 1.5 倍程度の大きさを示 した.

以上の結果は，定常円旋回時の自動車に作用する空気力を考えるときには，風洞実験で一般に検討されている 車体の横すべり運動が生じる流体力のみならず，曳航実験や数值シミュレーションなどを用いて，車体のヨー回 転運動によって生じる流体力を考慮することが重要であることを示唆している．本論文では一般的なセダン型乗 用車を対象に，それらの流体力特性を明らかにしたが，今後は車型や車両局所の形状などが同流体力特性に与え る影響について調査し，その影響について定量的に把握する必要がある.

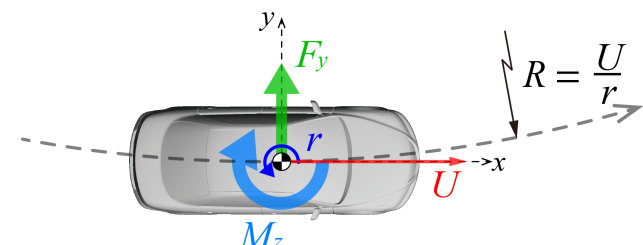

$\left(r>0: F_{y}>0, M_{z}<0\right)$

(a) The effect of the yaw rotational motion

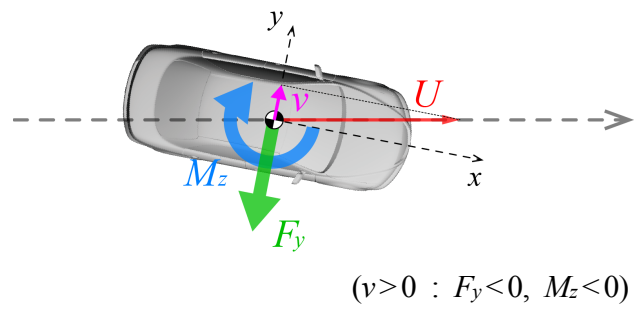

(b) The effect of the sideslip motion

Fig.9 Schematic views of the fluid-dynamic side force and yaw moment acting on a road vehicle in steady-state cornering. The effect of the yaw rotational motion aerodynamically generates a centripetal force of the circular motion and a moment suppressing the rotation. The effect of the sideslip motion generates a force suppressing the slip motion and a moment enhancing the vehicle's slip angle.

\section{謝 辞}

本研究は以下の支援により行われた : 文部科学省高性能汎用計算機高度利用事業「HPCI 戦略プログラム」分 野 4 次世代ものづくり (「自動車用次世代熱・空力設計システムの開発」における基礎検証課題として), 科研費 基盤研究 (B) No. 26289033 (実用ブラフボディの空力特性解明), 科研費基盤研究 (C) No. 26420115（ブラフボ ディの運動に伴う流体力発生メカニズムの考察).また, 広島大学大学院工学研究院の安川宏紀教授と平田法隆助 教には，曳航水槽試験装置の使用にあたって多くの貴重な助言を頂いた．広島大学大学院工学研究科の藤本創氏

(現 三菱重工業株式会社) には，曳航試験の実施にあたり多大な協力を頂いた。ここに記して, 各位への謝意を 表する.

\section{文献}

安倍正人, 自動車の運動と制御 : 車両運動力学の理論形成と応用 第 2 版(2012), 東京電機大学出版局, p.72. 赤崎繁, 重光蔟, 渡邊恵弘, 船の旋司中の見掛の水の質量に就て(第 1 報), 造船協会会報, Vol.69 (1942), pp.115-140. Cheng, S.Y., Tsubokura, M., Okada, Y., Nouzawa, T., Nakashima, T. and Doh, D.H., Aerodynamic stability of road vehicles in dynamic pitching motion, Journal of Wind Engineering and Industrial Aerodynamics, Vol.122 (2013), pp.146-156. ISO13674-1, Road vehicles - Test method for the quantification of on-centre handling - Part 1: Weave test (2010). 金井誠, 駒徹郎, 青木清平, 宮田秀明, 山下高明, 地面効果を受ける進行物体に働く流体力, 日本造船学会論文集 Vol.170 (1991), pp. 73-81.

河上充佳, 佐藤範和, Aschwanden Peter, 加藤由博, 中川雅樹, 小野英一, 動的空力解析に基づく簡易車両模型の非

定常空気力モデル，日本機械学会論文集 C 編, Vol.76, No.768 (2010), pp.2006-2015. 元良誠三, 航路安定性に就て, 造船協会会報, Vol.77 (1955), pp.69-90. 
農沢隆秀，岡田義浩，大平洋樹，岡本哲，中村貴樹，自動車の空気抵抗を増大させる車体周りの流れ構造 : 第 2 報,セダン車体の特徵的な流れ構造，日本機械学会論文集 B 編, Vol.75, No.757 (2009), pp.1807-1813.

岡田義浩, 農沢隆秀, 坪倉誠, 中島卓司, 自動車の高速操舵走行時の安定性に寄与寸る車体周りの非定常流れ特 性，日本機械学会論文集, Vol.80, No.809 (2014), DOI：10.1299/transjsme.2014smm0009.

佐藤博文, 原口哲之理, 大沢洋, 操舵感に関わる操舵応答特性の考察, 自動車技術, Vol. 44, No. 3 (1990), pp.52-58.

佐藤範和, 河上充佳, 加藤由博, 稲垣昌英, 堀之内成明, ALE 手法を用いた運動する車両周りの非圧縮性 LES 解 析：第 3 報,上下運動する簡易車両模型の非定常空力解析，日本機械学会論文集 B 編，Vol.76， No.770 (2010), pp.1515-1524.

Theissen, P., Wojciak, J., Heuler, K., Demuth, R., Indinger, T. and Adams, N., Experimental investigation of unsteady vehicle aerodynamics under time-dependent flow conditions - Part 1, SAE Technical Paper, No.2011-01-0177 (2011).

Tsubokura, M., Ikawa, Y., Nakashima, T., Okada, Y., Kamioka, T. and Nouzawa, T., Unsteady vehicle aerodynamics during a dynamic steering action: 2nd report, numerical analysis, SAE International Journal of Passenger Cars - Mechanical System, Vol.5, No.1 (2012), pp. 340-357.

\section{References}

Abe, M., Automotive vehicle dynamics: theory and applications 2nd edition (2012), p.72, Tokyo Denki University Press (in Japanese).

Akasaki, S., Shigemitsu, A. and Watanabe, Y., On the virtual water masses of ship while turning, Journal of Zosen Kiokai, Vol.69 (1942), pp.115-140 (in Japanese).

Cheng, S.Y., Tsubokura, M., Okada, Y., Nouzawa, T., Nakashima, T. and Doh, D.H., Aerodynamic stability of road vehicles in dynamic pitching motion, Journal of Wind Engineering and Industrial Aerodynamics, Vol.122 (2013), pp.146-156.

ISO13674-1, Road vehicles -Test method for the quantification of on-centre handling - Part 1: Weave test (2010).

Kanai, M., Koma, T., Aoki, K., Miyata, H. and Yamasita, T., Hydrodynamical forces on a moving body in ground effect, Journal of the Society of Naval Architects of Japan, Vol.170 (1991), pp.73-81 (in Japanese).

Kawakami, M., Sato, N., Aschwanden P., Kato, Y., Nakagawa, M. and Ono, E., A modeling of unsteady aerodynamic forces based on the aerodynamic analyses around a simplified car model in periodic motions, Transactions of the Japan Society of Mechanical Engineers. Series C, Vol.76, No.768 (2010), pp.2006-2015 (in Japanese).

Motora, S., Course stability of ships, Journal of Zosen Kiokai, Vol.77 (1955), pp. 69-90 (in Japanese).

Nouzawa, T., Okada, Y., Ohira, H., Okamoto, S. and Nakamura, T., Flow structure around vehicle increasing aerodynamic drag : 2nd report, characteristic flow structure of sedan vehicle, Transactions of the Japan Society of Mechanical Engineers. Series B, Vol. 75, No.757 (2009), pp. 1807-1813 (in Japanese).

Okada, Y., Nouzawa, T., Tsubokura, M. and Nakashima, T., Characteristics of unsteady flow around a vehicle affecting its high-speed stability during a dynamic steering action, Transactions of the JSME (in Japanese), Vol.80, No.809 (2014), DOI : $10.1299 /$ transjsme.2014smm0009.

Sato, H., Haraguchi, T. and Osawa, H., Experimantal analysis of steering response characteristics and steering feeling, Journal of the Society of Automotive Engineers, Vol. 44, No. 3 (1990), pp.52-58 (in Japanese).

Sato, N., Kawakami, M., Kato, Y., Inagaki, M. and Horinouchi, N., LES analysis of incompressible flows around an automobile in motion using ALE method : 3rd report, unsteady aerodynamic analysis around a simplified car model in heave motion, Transactions of the Japan Society of Mechanical Engineers. Series B, Vol.76, No.770 (2010), pp.1515-1524 (in Japanese).

Theissen, P., Wojciak, J., Heuler, K., Demuth, R., Indinger, T. and Adams, N., Experimental investigation of unsteady vehicle aerodynamics under time-dependent flow conditions - Part 1, SAE Technical Paper, No.2011-01-0177 (2011).

Tsubokura, M., Ikawa, Y., Nakashima, T., Okada, Y., Kamioka, T. and Nouzawa, T., Unsteady vehicle aerodynamics during a dynamic steering action: 2nd report, numerical analysis, SAE International Journal of Passenger Cars - Mechanical System, Vol.5, No.1 (2012), pp. 340-357. 